\title{
Australasian College of Sports Physicians-position statement: the place of mesenchymal stem/stromal cell therapies in sport and exercise medicine
}

\author{
Hamish Osborne, ${ }^{1}$ Lynley Anderson, ${ }^{2}$ Peter Burt, ${ }^{1}{ }^{1,2}$ Mark Young, ${ }^{3}$ David Gerrard
}

${ }^{1}$ Department of Medicine, Dunedin School of Medicine, University of Otago, Dunedin, New Zealand

${ }^{2}$ Bioethics Centre, University of Otago, Dunedin, New Zealand

${ }^{3}$ Mater Medical Research, University of Queensland and Queensland Institute of Technology, Brisbane, Australia

\section{Correspondence to}

Dr Hamish Osborne,

Department of Medicine

Dunedin School of Medicine,

University of Otago, P.O. Box

56, Dunedin 9054, New

Zealand; hamish.osborne@

otago.ac.nz

This paper is a joint publication with the Clinical Journal of Sport Medicine

Accepted 16 November 2015 Published Online First 23 December 2015
CrossMark

To cite: Osborne $\mathrm{H}$,

Anderson L, Burt P, et al. $\mathrm{Br}$ J Sports Med

2016:50:1237-1244.

\section{ABSTRACT}

Purpose and scope This Position Statement has been written expressly for members of the Australasian

College of Sports Physicians (ACSP); however, it may also be of interest to the wider medical community, sporting organisations, athletes and the general community. It has been informed by a comprehensive review of the scientific literature and the opinions of kindred organisations. This statement outlines the use of mesenchymal stem cell (MSC) therapies in the broad context of Sport and Exercise Medicine, recognising that every medical practitioner should respect: (1) the evidence for the therapeutic use of MSCs and (2) the priority for patient health and welfare.

\section{INTRODUCTION}

\section{Mesenchymal stem cells}

While many types of stem cell exist, they all possess two distinct properties. First, the ability to self-replicate (proliferate), and second, their potency or ability to differentiate (transform into mature adult tissue). Stem cells derived from and returned to the donor are termed 'autologous', while those administered to a non-tissue-matched recipient are referred to as 'allogeneic' stem cells.

Mesenchymal stem cells (MSCs) are derived from stromal tissue and described as multipotent, having the capacity to differentiate into mesodermal and endodermal types of cells, depending on the tissue matrix. ${ }^{1}$ Their multipotency, specific surface antigen expression and their plastic adherence properties when cultured are required for the definition of MSCs. ${ }^{2}$

This Position Statement only applies to MSC therapies and not to embryonic, haematopoietic or induced pluripotent stem cells; cellular therapies involving autologous tenocytes, autologous chondrocytes or platelet therapies.

\section{Expanding MSC populations}

MSCs can be extracted from adipose and synovial tissue, peripheral blood, skeletal muscle, umbilical cord blood, placenta, and bone marrow. Generating high numbers of MSCs requires several steps. First, harvesting, commonly from bone marrow or adipose tissue, then a stage of isolation and finally encouragement to proliferate. This MSC expansion process takes several weeks, is costly, highly technical but devoid of a 'gold standard'. The resulting manufactured cells are called mesenchymal stromal cells or mesenchymal progenitor cells. The MSC expansion processes result in variable cell populations with different cellular properties. ${ }^{3}$ The expanded cell populations also display reduced migration differentiation with consequences on their capacity for graft formation. ${ }^{4-8}$ The lack of standardisation between the commercially available MSC expansion protocols makes comparisons between products and studies relating to those products difficult. ${ }^{9}$

A contemporary development in manufacturing techniques employs far shorter preparation times (often less than $2 \mathrm{~h}$ ) at far less cost, producing a non-expanded mixed cell population. However, MSC numbers are low in these preparations, and the presence of multiple cell types raises questions about the efficacy of these techniques. ${ }^{10}$ While the progress in biotechnology has resulted in commercially attractive outcomes, the science substantiating their effectiveness has lagged behind. This has been called an 'unhealthy system'. ${ }^{11}$ No published randomised controlled trials for 'same-day bone marrow stem cell concentrates' are available as of $2015 .^{10} 12$

\section{MSCs and their therapeutic utility}

MSCs secrete growth factors and cytokines with trophic, chemotactic and immunosuppressive properties. $^{2} \begin{array}{llll}7 & 8 & 13 & 14 \\ \text { Experimental studies in animals }\end{array}$ show their potential for influencing musculoskeletal tissue regeneration and enhancement rather than fundamental repair, as would occur in simple scar formation. ${ }^{15-17}$ Therefore, MSCs have a potential regenerative influence on tissues damaged by repetitive overuse or through age-related degeneration. The pre-programming of MSCs to form a specific tissue has intriguing theoretical consequences for tissue regeneration and potential enhancement.

Given their low numbers, MSC populations for therapeutic use need to be expanded as outlined earlier. The ideal prerequisites for a satisfactory graft are large numbers of viable MSCs that do not age prematurely, and with the capacity to differentiate accurately into the correct cell type of the target site. Some consider that before clinical trials proceed it is important to determine that the success of the graft as the consequence of MSC activity rather than the paracrine effects of the grafted material. ${ }^{18}$ There are still many unresolved challenges to the therapeutic use of MSCs. ${ }^{19}$

\section{Clinical trials and MSC therapies}

There is no evidence in the contemporary literature of any MSC therapy for use in musculoskeletal conditions having successfully completed a full clinical trial in accordance with the steps mandated by the International Society for Stem Cell Research. ${ }^{20}$ 
This protocol strictly adheres to a four-phase model of clinical trial necessary for any novel therapeutic intervention. Consequently, current variants of MSC therapy advanced by clinicians throughout Australasia have limited scientific credibility, may not meet the requirements for evidence-based clinical practice nor satisfy the criteria for patient safety. ${ }^{21}$

The fundamental steps of the widely accepted clinical trial process $^{22} 23$ include:

Phase I: Researchers test the safety and assess adverse effects of an intervention in a small cohort of participants.

Phase II: The intervention is administered to a larger group to assess efficacy and to further evaluate safety.

Phase III: The treatment is administered to large identified groups of participants to confirm effectiveness, monitor side effects, provide comparisons with commonly used treatments, and to collect information that will inform future safe treatment

Phase IV: Postmarket surveillance is undertaken (after the introduction of the therapy to clinical practice) to assess any adverse effects associated with long-term use.

There have been a number of concerns raised about the use of MSCs in clinical practice in the absence of evidence of clinical efficacy. This paper will address the scientific and ethical concerns.

\section{SAFETY}

MSCs by definition have the ability to transform/differentiate into a limited number of mature cell types (multipotency), making them different from embryonic stem cells that have pluripotent differentiation potential. This makes MSCs a safer option. However, questions remain including:

- Do MSCs have a tumorigenic effect?

- What is the mechanism of action of the therapeutic effect?

- Is greater therapeutic effect associated with greater risk?

- Do MSCs stimulate currently dormant tumour cells within the recipient?

Before phase I research can start, often preclinical animal models are used to better understand safety and adverse effects of innovative biological therapies. Suitable models for comparison to humans may be available, ${ }^{24}$ but sometimes artificial biological models need to be developed to mimic human disease state to assess biological response. ${ }^{24}$

Safety studies need to be rigorous in design including strong institutional framework of peer review in the development phase, stringent ethical approval, implementation and follow-up to predetermined measurable and clinically relevant end points. $^{25}$

A systematic review and meta-analysis (2012) of the intravenous use of $\mathrm{MSCs}^{14}$ in 321 patients with a diverse group of medical conditions, including Crohn's disease, stroke, myocardial infarction and cardiomyopathy, found their use to be safe. However, there have been three subsequent case reports of similar interventions that describe significant side effects-ventricular fibrillation, pulmonary emboli and acute disseminated encephalomyelitis. $^{26-28}$

Malignancy associated with pluripotent stem cells in preclinical studies is of concern. In the case of MSCs, quality evidence of the risk of malignant transformation in humans is lacking. ${ }^{13} 14$ There is a case report of transplanted autologous cells presumed to be MSCs, causing a tumour 8 years later. ${ }^{29}$ The literature continues to question the potential for stem cell use to unmask dormant malignancy. ${ }^{13}$ A study of bone marrow-derived stem cells cultured for 4 weeks showed two of five cultures formed sarcoma-like tumours in vitro. ${ }^{31}$ A 4 -week culture time is longer than MSCs currently available from commercial techniques; however, their tumour-forming potential remains a concern. If research suggests that larger numbers of stem cells are required for efficacy, then techniques of in vitro culture deserve further investigation. Only then can their in vivo application be considered to have no potential for tumourogenesis.

To date, research into the safe use of MSCs has not demonstrated tumour-forming potential or other significant side effects in phases I and II musculoskeletal research. ${ }^{32-34}$ However, longterm safety cannot be assured. By way of example, agents later withdrawn for reasons of safety include the COX-2 Inhibitors Rofecoxib $^{35}{ }^{36}$ (Vioxx) and Lumiracoxib ${ }^{37}$ (Prexige). Both were withdrawn from the Australasian market several years after their introduction due to significant morbidity and mortality not evident in phases I and II research ${ }^{38}$ but discovered through vigilant postmarketing research (phase IV) after thousands of patients had been treated.

\section{Safety in osteoarthritis}

A systematic review ${ }^{32}$ of the safety of autologous bone marrowderived MSCs in the treatment of osteoarthritis reviewed 3039 articles and found eight articles that met their inclusion criteria. $^{39-46}$ In total, 844 procedures were followed for a mean of 21 months. Increased pain and swelling after the injection were the only adverse events reported as being related to the stem cell product. Importantly, the authors concluded that it is safe to continue development of stem cell therapies provided there is 'continuous caution for potential side effects'. ${ }^{32}$

A phase I/II double-blind, randomised controlled trial of 59 patients injected postarthroscopic meniscal surgery showed no difference between minor and major side effects between the low dose $\left(50 \times 10^{6}\right.$ cells $)$, high dose $\left(150 \times 10^{6}\right.$ cells $)$ and control groups and no ectopic tissue formation. The MSCs were from bone marrow aspirates of unrelated donors (allograft). ${ }^{47}$

A further study of 91 patients in whom 100 joints were injected with autologous adipose MSCs were followed for an average of 26 months. No tumours were reported. ${ }^{48}$ However, swelling of the injected joints was reported as a common, but self-limiting side effect.

Several small studies have used MSCs as an adjunct to surgical intervention for the treatment of osteochondral defects in the ankle and knee. ${ }^{4-54}$ A total of 101 patients received MSCs compared with 51 control patients who had surgery without MSCs. There were no reported differences in significant adverse effects between groups.

Three small phase I/II studies comparing high tibial osteotomy $(n=66)$ with high tibial osteotomy plus MSCs $(n=74)$ showed no significant side effects between groups after a 2-year follow-up. ${ }^{55-57}$ There are other studies involving orthopaedic intervention, where MSCs were used as an adjunct, without any reported significant side effects. ${ }^{42} 58-62$

\section{Safety in tendinopathy}

Few studies have examined the treatment of tendinopathy in humans with MSCs. ${ }^{24} 30333463$

Two case series treating patellar tendinopathy ${ }^{33}$ and 30 patients with lateral epicondylosis ${ }^{34}$ with bone marrow-derived non-expanded MSCs followed for 5 years and 12 weeks, respectively, reported no significant adverse effects. Another small series of 14 patients who had bone marrow-derived nonexpanded MSCs injected around the surgical repair margins of full thickness rotator cuff repairs followed for 12 months showed no adverse outcomes. ${ }^{63}$ 
One pilot study reported using cultured human tenocytes in the treatment of tendinopathy without any adverse effects. ${ }^{30}$ However, the use of tenocytes is not within the scope of this report.

\section{Safety in muscle injury}

There are no data in the literature that address the safety of MSCs in human muscle injury. ${ }^{24}$ Questions have been raised about the possibility of heterotopic bone formation in injured muscle treated with MSCs. ${ }^{64-66}$

\section{EFFICACY}

There are promising studies that MSCs enhance tendon repair in rabbit, ${ }^{15}$ rat $^{67}$ and horse ${ }^{68}$ models.

MSCs have been demonstrated both in vitro ${ }^{69}$ and in vivo ${ }^{70}$ to be able to differentiate into articular cartilage, thus suggesting they may be useful for treating articular cartilage injuries.

There is biological plausibility that MSCs should be therapeutic in the management of osteoarthritis. Laboratory-based evidence demonstrates MSC-mediated catabolic and inflammatory effects that should be chondroprotective. ${ }^{71} 72$

Osteoarthritis differs from an osteochondral defect. The former is a dynamic process where mechanical stressors and catabolic processes overwhelm the joints capacity for repair, whereas the latter can be an acute injury or metabolic condition. MSC research outcomes must be carefully considered before extrapolating from one pathology to the other.

Introducing standards to MSC treatment, for example, how many cells should be injected, will make it easier to analyse treatment outcomes but may lead to debate when companies are already marketing MSC products that have different processes and cell concentrates based on inadequate science. ${ }^{73-75}$

Animal models suggest that where MSCs are derived from tissue that is similar to the target organ, the better the outcomes. Human research suggests this is also a consideration. Adipose tissue offers a readily available source of MSCs; however, these tissues are dissimilar to musculoskeletal tissue. How adipose-derived MSCs compare to those derived from tissue similar to the target organ requires further research. Whether cells need culture or can be injected in same day procedures also needs further investigation. How many MSCs are required to achieve any therapeutic outcome remains unanswered. $^{76} 77$

\section{Efficacy in osteoarthritis}

The most appropriate method to determine if an intervention has a placebo effect is to undertake a double-blind, placebo randomised controlled trial (level 2 evidence). To date, there are no published studies of this calibre.

There are several small ${ }^{39-41} 434778-86$ and one large ${ }^{87}$ cohort study where injected MSCs showed improved pain and functional scores. Some reported evidence of arthroscopic or radiographic improvements to the articular cartilage at follow-up. ${ }^{41} 4347$ 78-82 8586

There are several small studies comparing MSCs to hyaluronic acid-one 7-10 days postarthroscopic debridement, ${ }^{47}$ the others not related to surgery. ${ }^{47} 88$ While the MSCs were better than hyaluronic acid in the surgical group and equivalent to hyaluronic acid in the non-surgical group, it is difficult to fully interpret these results due to the nature of the comparison groups. Arthroscopic debridement surgery has been shown to worsen patient outcomes in knee arthritis, ${ }^{89} 90$ and it remains unproven whether hyaluronic acid is therapeutic. ${ }^{91}$ It is not known whether MSCs ameliorate the detrimental effect of surgery and allow more acceptable surgical outcomes. Likewise comparing MSCs to a treatment with unproven outcomes is challenging to interpret.

The Osteoarthritis Stem Cell Advanced Research Study (OSCARS) remains the only double-blind, randomised placebocontrolled trial using injected MSCs for knee osteoarthritis. It demonstrates no difference in efficacy between the treatment group (receiving non-expanded adipose derived MSCs) and those who had MSCs harvested but received a saline control injection at any point out to 12 months follow-up. ${ }^{92} 93$ Although published as a conference abstract, ${ }^{93}$ the full study remains unpublished in a peer-reviewed journal.

\section{Efficacy in tendinopathy}

While there are a large number of articles looking at animal tendinopathies, many use collagenase-induced injuries rather than the clinical scenario seen in humans of overuse or age-related tendon degeneration. ${ }^{24}$ Two studies examining the equine equivalent of Achilles tendinopathy demonstrated a decrease in tendon reinjury rates compared with historical veterinary data. ${ }^{24}$ Animal models suggest that MSCs alone have less efficacy without the presence of a biological 'scaffold' and/or growth factors. This would suggest that without the scaffold and cytokine influence, the MSC effect is predominantly paracrine rather than the MSCs themselves integrating into the repair. $^{16} 2494-99$ A review article (2013) was unable to find any completed clinical studies using autologous MSCs in tendon repair. $^{24}$

\section{Efficacy in muscle injury}

MSCs exist in skeletal muscle. Homoeostasis and healing/repair of muscle is complex. ${ }^{100}$ To date, no literature has examined autologous MSC use in muscle healing. ${ }^{24}$

\section{ETHICAL CONCERNS REGARDING MSC USE IN MUSCULOSKELETAL CONDITIONS}

The underlying ethical values important to the everyday work of sports physicians are also pertinent when considering the use of MSCs for musculoskeletal conditions. Respect for patient autonomy while promoting benefit and avoiding harm, and acting in a fair and just manner are some of the important ethical concepts that can be used to usefully reflect on this relatively new area of work. ${ }^{101-107}$

New developments in healthcare have the potential to benefit many. However, patients can be harmed as a result of the introduction of new therapies with insufficient evidence to support their widespread use. ${ }^{35-38} 8990108$ Therefore, good quality research is needed to ensure that innovations are safe and efficacious prior to wider clinical use. ${ }^{106} 108109$ A balance must be struck that allows for a level of innovation, yet ensures that patient safety is paramount through the use of robust research to ensure safety and efficacy.

MSC therapy is an area of collaboration between the medical profession, and commercial and non-commercial interdisciplinary groups in an area where the science is preliminary, not all the evidence is in the public domain and the regulations are evolving. ${ }^{669293}$ Other countries have developed regulations to protect the consumer, ${ }^{110-114}$ but adherence to those regulations have varied. $.^{75} 110112115-117$ On some occasions, clinicians have ignored practice constraints and others have exploited regulatory 'loopholes" 21116 allowing treatments to be marketed to the public bypassing standards for innovative therapies coming to market. 
The use of autologous MCSs for the treatment of musculoskeletal conditions is currently unproven, and therefore has not yet been determined to be safe or efficacious for clinical use and there is a lack of credible long-term data to support clinical appli-

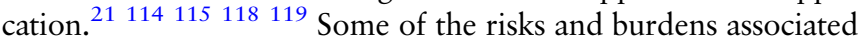
with MSC use are well recognised as they arise by virtue of their route of administration (including injection-site infection, and wrong-site administration). ${ }^{21}{ }^{112}$ Other aspects of MSC use where there are, as yet, no clear treatment guidelines may pose risks and potential harms that are yet to be determined, including cell preparation, dose and frequency, ${ }^{12}$ and any long-term harms that may eventuate. ${ }^{21}$ There is, therefore, a need to protect the patient from known and as yet unknown harms arising from new and unproven interventions. Not only must we consider the potential harms to an individual patient or research participant, but harms to the integrity of the medical profession and erosion of public trust in medical research ${ }^{116}$ through the unchecked practices of some clinics undertaking MSC therapy. Yet demand exists for new treatments in musculoskeletal care, particularly where the patient has few clinical options remaining. ${ }^{91} 106120$ Athletes and physically active members of the community seek rapid resolution of their musculoskeletal problems. Consequently, they may be willing to accept treatment options that have not been subjected to full clinical scrutiny, in an endeavour to obtain accelerated 'return to play'. These factors place pressure on doctors to consider new therapies where options are limited, but they also potentially leave patients vulnerable to exploitation. ${ }^{74}$

In recent years, there has been a proliferation of clinics offering, ${ }^{116}$ and sometimes actively marketing, MSCs for treatment of several musculoskeletal problems. Some clinics have overstated claims about the efficacy and safety of MSCs given the current knowledge. ${ }^{75} 115116119121$ Concern has also been raised about the high cost of care, the potential conflicts of interest clinicians might have, and the claims made in advertising given the absence of proven therapeutic benefit. Calls have been made for this area to be more stringently regulated. ${ }^{21} 115116$

So far, research in this area has revolved around autologous MSCs. Where research moves towards MSC allografts, the ethical considerations are more complicated and attract regulations to protect patients. ${ }^{122}$

There are also concerns that patients may travel outside of their home jurisdiction to receive MSC therapy where regulatory requirements are less rigorous. Australasian College of Sports Physicians (ACSP) members need to be cognisant of these concerns and to the pressures this activity may place on them. ${ }^{74} 101$

\section{Advertising}

As stated earlier, patients seeking MSC therapy have frequently reached the end of conventional treatment options; this may leave them particularly vulnerable to exploitation through the use of unwarranted claims of efficacy beyond what is currently known, or through testimonials from celebrity patients. ${ }^{112} 116123$

In both Australia and New Zealand, there is a clear expectation that advertisements or claims made about treatment must meet particular expectations. The Medical Board of Australia Code of Conduct ${ }^{104}$ states that:

Good medical practice involves:

8.6.1 Making sure that any information you publish about your medical services is factual and verifiable.

8.6.2 Making only justifiable claims about the quality or outcomes of your services in any information you provide to patients.
8.6.3 Not guaranteeing cures, exploiting patients' vulnerability or fears about their future health, or raising unrealistic expectations.

\subsubsection{Not offering inducements or using testimonials}

The New Zealand Medical Council statement on advertising states makes similar demands, requiring that claims about services are factual and verifiable, and that people are not encouraged to have unrealistic expectations. ${ }^{124}$ The New Zealand Medical Association Code of Ethics specifically states that testimonials and endorsements not be used. ${ }^{125}$

\section{ACSP POSITION}

The position adopted by the ACSP promotes patient safety and autonomy, endeavours to reduce potential harm to the patient, provides a level of clarity in an area of uncertainty, and takes responsibility for the advancement of knowledge. ${ }^{101} 106122$ The ACSP position protects patients and the profession in the absence of unequivocal evidence regarding effectiveness and safety of these techniques, and yet responds to a recognised need to actively contribute to the development of knowledge in this area. ${ }^{101} 126$ The ACSP believes that robust knowledge generation is vital to improving patient care. ${ }^{106}$

The ACSP believes that any use of MSCs for musculoskeletal conditions must fit within either of the following pathways:

1. As part of a rigorous clinical research trial.

2. As an individualised innovative therapy where there is a commitment to the transparent collection of data for analysis by a research body external to the clinic.

\section{As part of a rigorous clinical research trial}

The ACSP encourages the establishment of research studies to determine the safety and efficacy of MSC for the treatment of musculoskeletal conditions. MSC use for musculoskeletal conditions as part of a clinical research trial must be registered with an appropriate national or international clinical research trial registry. ${ }^{107} 114127128$ Any research trial must be subject to rigorous and independent scientific peer review prior to start of the study, and receive ethical approval from an accredited human research ethics committee. ${ }^{106} 107129$ It is expected that any and all research findings are shared within the scientific and medical community including adverse outcomes. ${ }^{106} 112129$

\section{As an individualised innovative therapy where there is a commitment to the transparent collection of data for analysis by a research body external to the clinic}

Innovation carries an expectation of improved patient care, and duties to the medical profession, and society at large. Duties include contributions to knowledge, collaboration with peers and information sharing. ${ }^{130}$

As the state of knowledge currently held about MSCs for musculoskeletal conditions is limited, offering this intervention beyond a clinical research trial would be considered to be innovative treatment. ${ }^{21} 106115116$ Innovative therapies are new or modified treatments undertaken in the best interests of the patient but with as yet unproven outcomes. Innovative practices are essential for medical progress, ${ }^{130}$ but should be subject to formal evaluation through rigorous peer-reviewed research. ${ }^{109}$ In the absence of robust research, innovative practices may become widely adopted without adequate data to determine risks and benefit; physicians are unable to determine safety and efficacy; and informed consent will be compromised. ${ }^{130}$

The clinical use of MSCs as innovative therapy must be recorded, including indications for treatment, clinical and demographic data, and clinical outcomes. These should be open to 
scrutiny and auditable as part of a commitment to knowledge generation and improving care. ${ }^{131}$ ACSP members should be willing to engage in practices that permit open and transparent scientific evaluation of such services by an independent external research body (analogous to the Australian and New Zealand Orthopaedic joint replacement registries ${ }^{132}{ }^{133}$ ). The research body will carry out scientific analysis of data. It would be expected that only small numbers of patients would go through this pathway, and would receive MSCs as part of individualised care decided on a case-by-case basis. ${ }^{21} 130$ Clinicians using MSCs as an innovative therapy should move to clinical trials in a timely fashion after experience with at most a few patients. ${ }^{21} 130$

\section{Informed consent}

In the interests of respecting patient autonomy, ACSP members will be required to inform patients about all aspects of their care, ${ }^{106}$ including whether they are part of a research trial, or are receiving innovative therapy. ${ }^{103}$

Any patients receiving MSC therapy under either pathway need to be made aware of and presented in writing the following:

- That MSCs are experimental and have not yet been proven to be safe or effective for clinical use.

- The long-term harms from the use of MSCs have not been determined.

- That the patient is being offered a therapy that has not been validated through reliable research methods.

- That identifiable personal patient or participant information and treatment will be entered into a database and accessed by researchers.

- That patients may be contacted at a later date for research purposes.

- That ethical approval will be sought prior to accessing patient data.

- Any conflicts of interest (including financial) held by the researcher or clinician providing innovative therapy will be declared.

- The full cost of the procedure, including a full break down of costs will be provided to the patient.

- Costs involved in MSC interventions used within research will not be passed onto participants as this has the potential to distort the research process. ${ }^{21} 134$

- Informed consent to the procedure or to participation in research will be obtained in writing.

All advertising for services must meet the standards of the Australian Medical Council and the Medical Council of New Zealand.

This position statement will be reviewed and updated if necessary in 2017.

\section{Summary}

- Mesenchymal stem cell therapies are still under investigation.

- Research evidence to date suggests mesenchymal stem cells may be safe in the treatment of osteoarthritis and tendinopathies, so that it is reasonable to proceed to further robust clinical trials with rigorous long-term follow-up.

- There is limited evidence that suggests that non-expanded mesenchymal stem cell therapies do not work. Further research is required to determine the safety and efficacy of expanded mesenchymal stem cells with and without biological scaffolds/growth factors.

- There is currently insufficient evidence from high-quality clinical trials to recommend the clinical use of mesenchymal stem cell therapies for joint or tendon regeneration.
- The ACSP believes that robust knowledge generation is vital to improving patient care.

- The ACSP encourages the establishment of research studies to determine the safety and efficacy of mesenchymal stem cells for the treatment of musculoskeletal conditions.

- Clinical research trials must be registered with an appropriate clinical research trial registry.

- Any research trial must be subjected to peer review, and receive human research ethics committee approval.

- Any and all research findings will be shared within the scientific and medical community including adverse outcomes.

- The ACSP position promotes patient safety and autonomy, endeavours to reduce potential harm to the patient, provides a level of clarity in an area of uncertainty, and takes responsibility for the advancement of knowledge.

- The ACSP position protects patients and the profession in the absence of unequivocal evidence regarding effectiveness and safety of these techniques, and yet responds to a recognised need to actively contribute to the development of knowledge in this area.

- The ACSP believes that any use of mesenchymal stem cells for musculoskeletal conditions must fit within either of the following pathways:

- As part of a rigorous clinical research trial.

- As an individualised innovative therapy. It is expected that only a few patients would go through this pathway before timely progression to clinical trials.

- The use of mesenchymal stem cells must only be undertaken within the expectations of the relevant medical regulatory organisations.

- ACSP members should engage in practices that permit open and transparent scientific evaluation of such services by an independent external research body.

- All indications for treatment, clinical and demographic data, and clinical outcomes should be open to scrutiny as part of a commitment to increasing knowledge and improving care.

- ACSP members must inform all patients receiving mesenchymal stem cell therapy that:

- They are part of a research trial, or are receiving innovative therapy.

- Mesenchymal stem cells are experimental and have not yet been proven to be safe or effective for clinical use.

- The long-term harms from the use of mesenchymal stem cells have not been determined.

- Identifiable personal patient or participant information and treatment will be entered into a database and accessed by researchers.

- They may be contacted at a later date for research purposes.

- Ethical approval will be sought prior to accessing patient data.

- Any conflicts of interest held by the researcher or clinician providing innovative therapy will be declared.

- The full cost of the procedure, including a full break down will be provided to the patient. Costs involved in mesenchymal stem cell interventions used within research will not be passed onto participants.

- Informed consent to the procedure will be obtained in writing.

Acknowledgements The authors thank Alison K McLean BSC (Hons) LLB (Hons), Sydney Medical School, University of Sydney and Grant R Gillett, Professor of Biomedical Ethics, University of Otago for their invaluable contributions to this manuscript. 
Contributors HO did the main literature review, wrote the first draft and contributed to the ongoing writing/review to the final document stage. LA wrote the first draft of the ethics section, reviewed the literature in this area and contributed to the ongoing writing/review to the final document stage. PB and DG contributed to the ongoing writing/review to the final document stage once $\mathrm{HO}$ and LA had the first draft ready. MY wrote the basic outline from which the first draft was prepared and then contributed to the ongoing writing/review to the final document stage.

Competing interests None declared.

Provenance and peer review Not commissioned; externally peer reviewed.

\section{REFERENCES}

1 Dimarino AM, Caplan Al, Bonfield TL. Mesenchymal stem cells in tissue repair. Front Immunol 2013:4:201.

2 Dominici M, Le Blanc K, Mueller I, et al. Minimal criteria for defining multipotent mesenchymal stromal cells. The International Society for Cellular Therapy position statement. Cytotherapy 2006;8:315-17.

3 Perez-Ilzarbe M, Diez-Campelo M, Aranda P, et al. Comparison of ex vivo expansion culture conditions of mesenchymal stem cells for human cell therapy. Transfusion 2009:49:1901-10.

4 Ankrum J, Karp JM. Mesenchymal stem cell therapy: two steps forward, one step back. Trends Mol Med 2010;16:203-9.

5 Banfi A, Muraglia A, Dozin B, et al. Proliferation kinetics and differentiation potential of ex vivo expanded human bone marrow stromal cells: implications for their use in cell therapy. Exp Hematol 2000;28:707-15.

6 Bonab MM, Alimoghaddam K, Talebian F, et al. Aging of mesenchymal stem cell in vitro. BMC Cell Biol 2006;7:14.

7 LaBarge MA, Blau HM. Biological progression from adult bone marrow to mononucleate muscle stem cell to multinucleate muscle fiber in response to injury. Cell 2002;111:589-601.

8 Phinney DG, Prockop DJ. Concise review: mesenchymal stem/multipotent stromal cells: the state of transdifferentiation and modes of tissue repair-current views. Stem Cells 2007;25:2896-902

9 Veronesi F, Giavaresi G, Tschon M, et al. Clinical use of bone marrow, bone marrow concentrate, and expanded bone marrow mesenchymal stem cells in cartilage disease. Stem Cells Dev 2013;22:181-92.

10 Sampson S, Botto-van Bemden A, Aufiero D. Autologous bone marrow concentrate: review and application of a novel intra-articular orthobiologic for cartilage disease. Phys Sportsmed 2013;41:7-18.

11 Eaves FF III. Got evidence? Stem cells, bias, and the level of evidence ladder: commentary on: "ASAPS/ASPS position statement on stem cells and fat grafting". Aesthet Surg J 2011;31:718-22.

12 Yu SP, Hunter DJ. Emerging drugs for the treatment of knee osteoarthritis. Expert Opin Emerg Drugs 2015:20:361-78.

13 Casiraghi F, Remuzzi G, Abbate M, et al. Multipotent mesenchymal stromal cell therapy and risk of malignancies. Stem Cell Rev 2013:9:65-79.

14 Lalu MM, McIntyre L, Pugliese C, et al. Safety of cell therapy with mesenchyma stromal cells (SafeCell): a systematic review and meta-analysis of clinical trials. PLOS ONE 2012;7:e47559.

15 Chong AK, Ang AD, Goh JC, et al. Bone marrow-derived mesenchymal stem cells influence early tendon-healing in a rabbit Achilles tendon model. J Bone Joint Surg Am 2007;89:74-81.

16 Longo UG, Lamberti A, Maffulli N, et al. Tissue engineered biological augmentation for tendon healing: a systematic review. Br Med Bull 2011:98:31-59.

17 Young RG, Butler DL, Weber W, et al. Use of mesenchymal stem cells in a collagen matrix for Achilles tendon repair. J Orthop Res 1998;16:406-13.

18 Wei CC, Lin AB, Hung SC. Mesenchymal stem cells in regenerative medicine for musculoskeletal diseases: bench, bedside, and industry. Cell Transplant 2014;23:505-12.

19 Bongso A, Fong $C Y$, Gauthaman K. Taking stem cells to the clinic: major challenges. J Cell Biochem 2008;105:1352-60.

20 International Society for Stem Cell Research. The Guidelines for the Clinical Translation of Stem Cells. 2008. http://www.isscr.org/docs/guidelines/ isscrglclinicaltrans.pdf (accessed 31 Jul 2015).

21 International Society for Stem Cell Research. Statement on Delivery of Unproven Autologous Cell-based Interventions to Patients. 2013. http://www.isscr.org/docs/ default-source/isscr-statements/isscr-acbistatement-091113-fl.pdf (accessed $22 \mathrm{Jul}$ 2015).

22 National Institute of Health. Glossary of Terms. 2001. http://grants.nih.gov/grants/ peer/tree_glossary.pdf (accessed 3 Aug 2015).

23 National Health and Medical Research Council. Phases of Clinical Trials. 2015. http://www.australianclinicaltrials.gov.au/what-clinical-trial/phases-clinical-trials (accessed 5 Aug 2015).

24 Davies BM, Morrey ME, Mouthuy PA, et al. Repairing damaged tendon and muscle: are mesenchymal stem cells and scaffolds the answer? Regen Med 2013;8:613-30
25 Gomez-Barrena E, Sola CA, Bunu CP. Regulatory authorities and orthopaedic clinical trials on expanded mesenchymal stem cells. Int Orthop 2014;38:1803-9.

26 Jung JW, Kwon M, Choi JC, et al. Familial occurrence of pulmonary embolism after intravenous, adipose tissue-derived stem cell therapy. Yonsei Med J 2013:54:1293-6.

27 Pytel P, Husain A, Moskowitz I, et al. Ventricular fibrillation following autologous intramyocardial cell therapy for inherited cardiomyopathy. Cardiovasc Pathol 2010;19:e33-6.

28 Kishk NA, Abokrysha NT, Gabr H. Possible induction of acute disseminated encephalomyelitis (ADEM)-like demyelinating illness by intrathecal mesenchymal stem cell injection. J Clin Neurosci 2013;20:310-12.

29 Dlouhy BJ, Awe 0, Rao RC, et al. Autograft-derived spinal cord mass following olfactory mucosal cell transplantation in a spinal cord injury patient. J Neurosurg 2014;21:618-22.

30 Wang A, Breidahl W, Mackie KE, et al. Autologous tenocyte injection for the treatment of severe, chronic resistant lateral epicondylitis: a pilot study. Am J Sports Med 2013;41:2925-32.

31 Pan Q, Fouraschen SM, de Ruiter PE, et al. Detection of spontaneous tumorigenic transformation during culture expansion of human mesenchymal stromal cells. Exp Biol Med (Maywood) 2014;239:105-15.

32 Peeters CM, Leijs MJ, Reijman M, et al. Safety of intra-articular cell-therapy with culture-expanded stem cells in humans: a systematic literature review. Osteoarthritis Cartilage 2013;21:1465-73.

33 Pascual-Garrido C, Rolón A, Makino A. Treatment of chronic patellar tendinopathy with autologous bone marrow stem cells: a 5-year-followup. Stem Cells Int 2012;2012:953510.

34 Singh A, Gangwar DS, Singh S. Bone marrow injection: A novel treatment for tennis elbow. J Nat Sci Biol Med 2014;5:389-91.

35 Curfman GD, Morrissey S, Drazen JM. Expression of concern reaffirmed. N Engl J Med 2006;354:1193-3.

36 Bombardier C, Laine L, Reicin A, et al. Comparison of upper gastrointestinal toxicity of rofecoxib and naproxen in patients with rheumatoid arthritis. VIGOR Study Group. N Engl J Med 2000;343:1520-8, 2 p following 28.

37 Unzueta A, Vargas HE. Nonsteroidal anti-inflammatory drug-induced hepatoxicity. Clin Liver Dis 2013;17:643-56, ix.

38 Hawkey CJ, Weinstein WM, Stricker K, et al. Clinical trial: comparison of the gastrointestinal safety of lumiracoxib with traditional nonselective nonsteroidal anti-inflammatory drugs early after the initiation of treatment-findings from the Therapeutic Arthritis Research and Gastrointestinal Event Trial. Aliment Pharmacol Ther 2008;27:838-45.

39 Centeno CJ, Schultz JR, Cheever M, et al. Safety and complications reporting update on the re-implantation of culture-expanded mesenchymal stem cells using autologous platelet lysate technique. Curr Stem Cell Res Ther 2011;6:368-78.

40 Davatchi F, Abdollahi BS, Mohyeddin M, et al. Mesenchymal stem cell therapy for knee osteoarthritis. Preliminary report of four patients. Int I Rheum Dis 2011;14:211-15.

41 Emadedin M, Aghdami N, Taghiyar L, et al. Intra-articular injection of autologous mesenchymal stem cells in six patients with knee osteoarthritis. Arch Iran Med 2012:15:422-8.

42 Haleem AM, Singergy AA, Sabry D, et al. The clinical use of human culture-expanded autologous bone marrow mesenchymal stem cells transplanted on platelet-rich fibrin glue in the treatment of articular cartilage defects: a pilot study and preliminary results. Cartilage 2010;1:253-61.

43 Lee KB, Wang VT, Chan YH, et al. A novel, minimally-invasive technique of cartilage repair in the human knee using arthroscopic microfracture and injections of mesenchymal stem cells and hyaluronic acid — a prospective comparative study on safety and short-term efficacy. Ann Acad Med Singapore 2012;41:511-17.

44 Wakitani S, Okabe T, Horibe $S$, et al. Safety of autologous bone marrow-derived mesenchymal stem cell transplantation for cartilage repair in 41 patients with 45 joints followed for up to 11 years and 5 months. I Tissue Eng Regen Med 2011;5:146-50

45 Teo BJ, Buhary K, Tai BC, et al. Cell-based therapy improves function in adolescents and young adults with patellar osteochondritis dissecans. Clin Orthop Relat Res 2013;471:1152-8.

46 Kasemkijwattana $C$, Hongeng $S$, Kesprayura $S$, et al. Autologous bone marrow mesenchymal stem cells implantation for cartilage defects: two cases report. J Med Assoc Thai 2011;94:395-400

47 Vangsness CT Jr, Farr J II, Boyd J, et al. Adult human mesenchymal stem cells delivered via intra-articular injection to the knee following partial medial meniscectomy: a randomized, double-blind, controlled study. J Bone Joint Surg Am 2014:96:90-8

48 Pak J, Chang JJ, Lee JH, et al. Safety reporting on implantation of autologous adipose tissue-derived stem cells with platelet-rich plasma into human articular joints. BMC Musculoskelet Disord 2013;14:337.

49 Kim YS, Park EH, Kim YC, et al. Clinical outcomes of mesenchymal stem cell injection with arthroscopic treatment in older patients with osteochondral lesions of the talus. Am J Sports Med 2013;41:1090-9. 
50 Kim YS, Lee HJ, Choi YJ, et al. Does an injection of a stromal vascular fraction containing adipose-derived mesenchymal stem cells influence the outcomes of marrow stimulation in osteochondral lesions of the talus? A clinical and magnetic resonance imaging study. Am J Sports Med 2014;42:2424-34.

51 Giannini S, Buda R, Vannini F, et al. One-step bone marrow-derived cell transplantation in talar osteochondral lesions. Clin Orthop Relat Res 2009;467:3307-20.

52 Giannini S, Buda R, Battaglia M, et al. One-step repair in talar osteochondral lesions: 4-year clinical results and t2-mapping capability in outcome prediction. Am J Sports Med 2013:41:511-18.

53 Wakitani S, Nawata M, Tensho K, et al. Repair of articular cartilage defects in the patello-femoral joint with autologous bone marrow mesenchymal cell transplantation: three case reports involving nine defects in five knees. J Tissue Eng Regen Med 2007;1:74-9.

54 Saw KY, Anz A, Siew-Yoke Jee C, et al. Articular cartilage regeneration with autologous peripheral blood stem cells versus hyaluronic acid: a randomized controlled trial. Arthroscopy 2013;29:684-94.

55 Koh YG, Kwon OR, Kim YS, et al. Comparative outcomes of open-wedge high tibial osteotomy with platelet-rich plasma alone or in combination with mesenchymal stem cell treatment: a prospective study. Arthroscopy 2014;30:1453-60

56 Wakitani S, Imoto K, Yamamoto T, et al. Human autologous culture expanded bone marrow mesenchymal cell transplantation for repair of cartilage defects in osteoarthritic knees. Osteoarthritis Cartilage 2002;10:199-206.

57 Wong KL, Lee KB, Tai BC, et al. Injectable cultured bone marrow-derived mesenchymal stem cells in varus knees with cartilage defects undergoing high tibial osteotomy: a prospective, randomized controlled clinical trial with 2 years' follow-up. Arthroscopy 2013;29:2020-8.

58 Silva A, Sampaio R, Fernandes R, et al. Is there a role for adult non-cultivated bone marrow stem cells in $A C L$ reconstruction? Knee Surg Sports Traumatol Arthrosc 2014;22:66-71

59 Koh YG, Choi YJ, Kwon OR, et al. Second-look arthroscopic evaluation of cartilage lesions after mesenchymal stem cell implantation in osteoarthritic knees. Am J Sports Med 2014;42:1628-37.

60 Filardo G, Madry $H$, Jelic $M$, et al. Mesenchymal stem cells for the treatment of cartilage lesions: from preclinical findings to clinical application in orthopaedics. Knee Surg Sports Traumatol Arthrosc 2013;21:1717-29.

61 Nejadnik H, Hui JH, Feng Choong EP, et al. Autologous bone marrow-derived mesenchymal stem cells versus autologous chondrocyte implantation: an observational cohort study. Am J Sports Med 2010;38:1110-16.

62 Buda R, Vannini F, Cavallo M, et al. Osteochondral lesions of the knee: a new one-step repair technique with bone-marrow-derived cells. J Bone Joint Surg Am 2010;92(Suppl 2):2-11.

63 Ellera Gomes JL, da Silva RC, Silla LM, et al. Conventional rotator cuff repair complemented by the aid of mononuclear autologous stem cells. Knee Surg Sports Traumatol Arthrosc 2012;20:373-7.

64 Rothrauff BB, Tuan RS. Cellular therapy in bone-tendon interface regeneration. Organogenesis 2014;10:13-28.

65 Steinert AF, Rackwitz L, Gilbert F, et al. Concise review: the clinical application of mesenchymal stem cells for musculoskeletal regeneration: current status and perspectives. Stem Cells Trans/ Med 2012;1:237-47.

66 Grange $S$. Current issues and regulations in tendon regeneration and musculoskeletal repair with mesenchymal stem cells. Curr Stem Cell Res Ther 2012;7:110-14

67 Huang TF, Yew TL, Chiang ER, et al. Mesenchymal stem cells from a hypoxic culture improve and engraft Achilles tendon repair. Am J Sports Med 2013:41:1117-25

68 Godwin EE, Young NJ, Dudhia J, et al. Implantation of bone marrow-derived mesenchymal stem cells demonstrates improved outcome in horses with overstrain injury of the superficial digital flexor tendon. Equine Vet J 2012;44:25-32.

$69 \mathrm{Ma} \mathrm{HL}$, Hung SC, Lin SY, et al. Chondrogenesis of human mesenchymal stem cells encapsulated in alginate beads. J Biomed Mater Res A 2003;64:273-81.

$70 \mathrm{Ma} \mathrm{HL}$, Chen TH, Low-Tone Ho L, et al. Neocartilage from human mesenchymal stem cells in alginate: implied timing of transplantation. J Biomed Mater Res A 2005;74:439-46.

71 Platas J, Guillen MI, del Caz MD, et al. Conditioned media from adipose-tissue-derived mesenchymal stem cells downregulate degradative mediators induced by interleukin-1 beta in osteoarthritic chondrocytes. Mediators Inflamm 2013;2013:357014.

72 Manferdini C, Maumus M, Gabusi E, et al. Adipose-derived mesenchymal stem cells exert antiinflammatory effects on chondrocytes and synoviocytes from osteoarthritis patients through prostaglandin E2. Arthritis Rheum 2013;65:1271-81.

73 Shen H. Stricter standards sought to curb stem-cell confusion. Nature 2013;499:389.

74 Zarzeczny A, Clark M. Unproven stem cell-based interventions \& physicians' professional obligations; a qualitative study with medical regulatory authorities in Canada. BMC Med Ethics 2014;15:75.
75 Munsie M, Hyun I. A question of ethics: selling autologous stem cell therapies flaunts professional standards. Stem Cell Res 2014;13(3 Pt B):647-53.

76 Centeno CJ. Clinical challenges and opportunities of mesenchymal stem cells in musculoskeletal medicine. PM $R$ 2014;6:70-7.

77 Bashir J, Sherman A, Lee $H$, et al. Mesenchymal stem cell therapies in the treatment of musculoskeletal diseases. PM R 2014;6:61-9.

78 Pak J, Lee JH, Lee SH. A novel biological approach to treat chondromalacia patellae. PLOS ONE 2013;8:e64569.

79 Orozco L, Munar A, Soler R, et al. Treatment of knee osteoarthritis with autologous mesenchymal stem cells: a pilot study. Transplantation 2013:95:1535-41.

80 Jo $\mathrm{CH}$, Lee $\mathrm{YG}$, Shin WH, et al. Intra-articular injection of mesenchymal stem cells for the treatment of osteoarthritis of the knee: a proof-of-concept clinical trial. Stem Cells 2014;32:1254-66.

81 Saw KY, Anz A, Merican S, et al. Articular cartilage regeneration with autologous peripheral blood progenitor cells and hyaluronic acid after arthroscopic subchondral drilling: a report of 5 cases with histology. Arthroscopy 2011;27:493-506

82 Orozco L, Munar A, Soler R, et al. Treatment of knee osteoarthritis with autologous mesenchymal stem cells: two-year follow-up results. Transplantation 2014:97:e66-8.

83 Centeno CJ, Schultz JR, Cheever M, et al. Safety and complications reporting on the re-implantation of culture-expanded mesenchymal stem cells using autologous platelet lysate technique. Curr Stem Cell Res Ther 2010;5:81-93.

84 Centeno CJ, Freeman MD. Percutaneous injection of autologous, culture-expanded mesenchymal stem cells into carpometacarpal hand joints: a case series with an untreated comparison group. Wien Med Wochenschr 2014:164:83-7.

85 Koh YG, Jo SB, Kwon OR, et al. Mesenchymal stem cell injections improve symptoms of knee osteoarthritis. Arthroscopy 2013;29:748-55.

86 Koh YG, Choi YJ, Kwon SK, et al. Clinical results and second-look arthroscopic findings after treatment with adipose-derived stem cells for knee osteoarthritis. Knee Surg Sports Traumatol Arthrosc 2015;23:1308-16.

87 Michalek J, Moster R, Lukac L, et al. Autologous adipose tissue-derived stromal vascular fraction cells application in patients with osteoarthritis. Cell Transplant 2015.

88 Vega A, Martin-Ferrero MA, Del Canto F, et al. Treatment of knee osteoarthritis with allogeneic bone marrow mesenchymal stem cells: a randomized controlled trial. Transplantation 2015;99:1681-90.

89 Roos H, Lauren M, Adalberth T, et al. Knee osteoarthritis after meniscectomy: prevalence of radiographic changes after twenty-one years, compared with matched controls. Arthritis Rheum 1998;41:687-93.

90 Englund M, Lohmander LS. Risk factors for symptomatic knee osteoarthritis fifteen to twenty-two years after meniscectomy. Arthritis Rheum 2004;50:2811-19.

91 Hunter DJ. Viscosupplementation for osteoarthritis of the knee. N Engl J Med 2015:372:1040-7.

92 Osteoarthritis Stem Cell Advanced Research Study (OSCARS). Interim report: a randomised double-blind, placebo-controlled trial of the efficacy and safety of autologous non-expanded adipose-derived stem cells in the treatment of knee osteoarthritis. Regenius Ltd, 2013:1-6.

93 March L, Hunter DJ, Fedorova T, et al. ARA oral abstracts - a randomised placebo controlled pilot study of autologous non-expanded adipose-derived mesenchymal stem cells in the treatment of knee osteoarthritis. Intern Med J 2013;43:1-6.

94 Nixon AJ, Watts AE, Schnabel LV. Cell- and gene-based approaches to tendon regeneration. J Shoulder Elbow Surg 2012;21:278-94.

95 Ahmad Z, Wardale J, Brooks R, et al. Exploring the application of stem cells in tendon repair and regeneration. Arthroscopy 2012;28:1018-29.

96 Lui PP, Rui YF, Ni M, et al. Tenogenic differentiation of stem cells for tendon repair-what is the current evidence? J Tissue Eng Regen Med 2011;5:e144-63.

97 Hogan MV, Bagayoko N, James R, et al. Tissue engineering solutions for tendon repair. J Am Acad Orthop Surg 2011;19:134-42.

98 Gott M, Ast M, Lane LB, et al. Tendon phenotype should dictate tissue engineering modality in tendon repair: a review. Discov Med 2011;12:75-84.

99 Tucker BA, Karamsadkar SS, Khan WS, et al. The role of bone marrow derived mesenchymal stem cells in sports injuries. J Stem Cells 2010;5:155-66.

100 Paylor B, Natarajan A, Zhang RH, et al. Nonmyogenic cells in skeletal muscle regeneration. Curr Top Dev Biol 2011;96:139-65.

101 Australasian College of Sports Physicians Code of Ethics and Professional Behaviour. 2008. http://acsp.org.au/acsp-policies/ (accessed 31 Jul 2015).

102 Australian Medical Association Code of Ethics. 2006. https://ama.com.au/ position-statement/ama-code-ethics-2004-editorially-revised-2006 (accessed 31 Jul 2015).

103 New Zealand Medical Council. Good Medical Practice. 2013. https://www.mcnz. org.nz/news-and-publications/good-medical-practice/ (accessed 31 Jul 2015).

104 Medical Board of Australia. Good Medical Practice: A Code of Conduct for Doctors in Australia. 2014. http://www.medicalboard.gov.au/Codes-Guidelines-Policies/ Code-of-conduct.aspx (accessed 31 Jul 2015). 
105 Beauchamp TL, Childress JF. Principles of biomedical ethics. 7th edn. Oxford University Press, 2012.

106 National Health and Medical Research Council. National Statement on Ethical Conduct in Human Research. 2015. https://www.nhmrc.gov.au/guidelinespublications/e72 (accessed 13 Aug 2015).

107 Therapeutic Goods Administration. Note for Guidance on Good Clinical Practice CPMP/ICH/135/95. 2014. https://www.tga.gov.au/publication/note-guidancegood-clinical-practice (accessed 13 Aug 2015).

108 McKinlay JB. From "promising report" to "standard procedure": seven stages in the career of a medical innovation. Milbank Mem Fund Q Health Soc 1981;59:374-411.

109 Lindvall 0, Hyun I. Medical innovation versus stem cell tourism. Science (New York, NY) 2009;324:1664-5.

110 Abbott A. Leaked files slam stem-cell therapy. Nature 2014;505:139-40.

111 Anz AW, Hackel JG, Nilssen EC, et al. Application of biologics in the treatment of the rotator cuff, meniscus, cartilage, and osteoarthritis. J Am Acad Orthop Surg 2014;22:68-79.

112 Notarangelo LD. Into the wild - the use and abuse of stem cells in clinical practice. Am J Hematol 2013:88:447-8.

113 Australian Government Therapeutic Goods Administration Legislation. 2015. http:// www.tga.gov.au/excluded-goods-order-no-1-2011-guideline-items-4o-4p-4q-and-4r (accessed 5 Aug 2015).

114 National Health and Medical Research Council. Stem Cell Treatments-A Quick Guide for Medical Practitioners Stem Cell Treatments. 2013. https://www.nhmrc. gov.au/guidelines-publications/rm001 (accessed 31 Jul 2015).

115 McLean AK, Stewart C, Kerridge I. Untested, unproven, and unethical: the promotion and provision of autologous stem cell therapies in Australia. Stem Cell Res Ther 2015;6:33.

116 McLean AK, Stewart C, Kerridge I. The emergence and popularisation of autologous somatic cellular therapies in Australia: therapeutic innovation or regulatory failure? J Law Med 2014;22:65-89.

117 Cyranoski D. Stem cells in Texas: Cowboy culture. Nature 2013;494:166-8.

118 The National Stem Cell Foundation of Australia and Stem Cells Australia. The Australian Stem Cell Handbook. 2015. http://www.stemcellfoundation.net.au/ stem-cell-treatments-information/handbook (accessed 31 Jul 2015).

119 National Health and Medical Research Council. Stem Cell Treatments_Frequently Asked Questions. 2013. http://www.nhmrc.gov.au/_files_nhmrc/publications/ attachments/rm001a_stem_cell_treatments_faq_131220.pdf (accessed 13 Aug 2015).
120 Messier SP, Mihalko SL, Legault C, et al. Effects of intensive diet and exercise on knee joint loads, inflammation, and clinical outcomes among overweight and obese adults with knee osteoarthritis: the idea randomized clinical trial. JAMA 2013;310:1263-73.

121 Lau D, Ogbogu U, Taylor B, et al. Stem cell clinics online: the direct-to-consumer portrayal of stem cell medicine. Cell Stem Cell 2008;3:591-4.

122 Kirkpatrick B, Hercher L, Facio F, et al. Stem cell research and therapy: the position of the National Society of Genetic Counselors. J Genet Couns 2013;22: 407-10.

123 Banja JD. Ethical considerations in stem cell research on neurologic and orthopedic conditions. PM R 2015;7(4 Suppl):S66-75.

124 New Zealand Medical Council. Statement on advertising. 2015. https://www.mcnz. org.nz/assets/News-and-Publications/Statements/Statement-on-advertising.pdf (accessed 31 Jul 2015).

125 New Zealand Medical Association. Code of Ethics. 2013. https://www.nzma.org. nz/publications/code-of-ethics (accessed 22 Jul 2015).

126 Eaves FF III, Haeck PC, Rohrich RJ. ASAPS/ASPS Position statement on stem cells and fat grafting. Plast Reconstr Surg 2012;129:285-7.

127 Australian New Zealand Clinical Trials Registry. 2015 (6 Aug 2015). http://www. anzctr.org.au

128 World Health Organisation International Clinical Trials Registry Platform. Secondary World Health Organisation International Clinical Trials Registry Platform. 2015. http://www.who.int/ictrp/en/

129 National Health and Medical Research Council. Australian Code For The Responsible Conduct Of Research. 2007. http://www.nhmrc.gov.au/ guidelines-publications/r39 (accessed 13 Aug 2015).

130 ACOG Committee on Ethics. ACOG Committee Opinion No. 352: innovative practice: ethical guidelines. Obstet Gynecol 2006;108:1589-95.

131 World Medical Association Declaration of Helsinki. Ethical Prinicples for Medical Research Involving Human Subjects. 2008. http://www.wma.net/en/30publications/ 10policies/b3/ (accessed 20 Aug 2015).

132 AOA National Joint Registry. Secondary AOA National Joint Registry. 2015. https:/l aoanjrr.dmac.adelaide.edu.au

133 NZOA Joint Registry. Secondary NZOA Joint Registry. 2015. http://www.nzoa.org. nz/nz-joint-registry

134 New Zealand Ministry of Health National Ethics Advisory Committee. Ethical Guidelines of Intervention Studies: Revised Edition. 2012. http://neac.health.govt. $\mathrm{nz} /$ system/files/documents/publications/ethical-guidelines-for-interventionstudies-2012v2_0.pdf (accessed 26 Aug 2015). 